\title{
Adaptation and validation of the Sexual Sensation Seeking Scale for Portuguese higher education students
}

Adaptação portuguesa e validação da Sexual Sensation Seeking Scale para estudantes do ensino superior

Adaptación portuguesa y validación de la Sexual Sensation Seeking Scale para estudiantes de enseńanza superior

Maria José de Oliveira Santos*; Elisabete Maria Soares Ferreira**; João Carvalho Duarte**;

Manuela Maria da Conceição Ferreira****

\begin{abstract}
Background: The use of personality assessment tools is essential not only to understand sexual behaviors but also to develop nursing interventions for the prevention of sexual risk behaviors.

Objectives: Adaptation and validation of the Sexual Sensation Seeking Scale (SSSS) for Portuguese higher education students.

Methodology: Descriptive and correlational study using a sample of 1,946 college students aged 18 to 29 years. The final sample was composed of 1500 students who already had sexual intercourse. The psychometric characteristics of SSSS were assessed using 2 randomized subgroups.

Results: The exploratory factor analysis revealed a two-factor structure with 9 items, which explained $54.80 \%$ of the total variance. The model showed a good internal consistency $(\alpha=0.789)$. The confirmatory factor analysis confirmed the adequate goodness-of-fi of the modified model.

Conclusion: The instrument has good validity, fidelity, and reliability, and can be used to assess young people's sexual sensation seeking behaviors.
\end{abstract}

Keywords: sexual behavior; students; education, higher; validation studies; sensation seeking

\section{Resumo}

Enquadramento: A utilização de instrumentos de avaliaçấo de traços de personalidade é importante, não só na compreensão dos comportamentos sexuais, mas também no desenvolvimento de intervençóes de enfermagem que visem a prevençáa de comportamentos sexuais de risco.

Objetivos: Proceder à adaptação e validação da Sexual Sensation Seeking Scale (SSSS) para estudantes portugueses do ensino superior.

Metodologia: Estudo descritivo-correlacional, realizado numa amostra de 1946 estudantes, com idades compreendidas entre 18-29 anos. Da amostra global considerámos os 1500 estudantes que já tinham iniciado relaçóes sexuais. As características psicométricas da SSSS foram avaliadas em 2 subgrupos aleatorizados da amostra inicial.

Resultados: Os resultados da análise fatorial exploratória induziram a uma solução fatorial bidimensional com 9 itens, que explica $54,80 \%$ da variância e que apresentam uma boa consistência interna $(\alpha=0,789)$. Da análise fatorial confirmatória conclui-se que o ajustamento do modelo modificado é satisfatório.

Conclusáo: Este instrumento possui bons níveis de validade e fidelidade e confiabilidade, que permitem considerar a sua utilizaçáo para avaliar a busca de sensaçóes sexuais em jovens adultos.

Palavras-chave: comportamento sexual; estudantes; ensino superior; estudos de validação; sensaçóes sexuais

*MSc., Adjunct Professor, School of Health, University of Trás-os-Montes and Alto Douro, 5000-801, Vila Real, Portugal [mjsantos@utad.pt]. Contribution to the article: literature search; data collection; statistical treatment and evaluation; data analysis and discussion; article writing. Address for correspondence: Rua Emílio Biel, 15, 5000-050, Vila Real, Portugal. **Ph.D., Assistant Professor, Faculty of Psychology and Education Sciences, University of Porto, 4200-135, Porto, Portugal [elisabete@fpce.up.pt]. Contribution to the article: research design; final revision.

***Ph.D., Coordinating Professor, Health School of Viseu, Polytechnic Institute of Viseu, 3500-843, Viseu, Portugal [duarte.johnny@gmail.com]. Contribution to the article: statistical treatment and evaluation; data analysis and discussion; article revision.

****Ph.D., Coordinating Professor, Health School of Viseu, Polytechnic Institute of Viseu, 3500-843, Viseu, Portugal [mmcferreira@gmail.com].Contribution to the article: research design; data analysis and discussion; article revision.

\section{Resumen}

Marco contextual: La utilización de instrumentos de evaluación de rasgos de la personalidad es importante, no solo para comprender los comportamientos sexuales, sino también para desarrollar intervenciones de enfermería cuyo objetivo sea prevenir los comportamientos sexuales de riesgo.

Objetivos: Proceder a la adaptación y validación de la Sexual Sensation Seeking Scale (SSSS) para estudiantes portugueses de enseńanza superior.

Metodología: Estudio descriptivo-correlacional, realizado en una muestra de 1946 estudiantes con edades comprendidas entre los 18 y los 29 ańos. De la muestra global se consideraron los 1500 estudiantes que ya habían tenido relaciones sexuales. Las características psicométricas de la SSSS se evaluaron en 2 subgrupos aleatorizados de la muestra inicial.

Resultados: Los resultados del análisis factorial exploratorio indujeron a una solución factorial bidimensional con 9 ítems, lo que explica el 54,80\% de la varian$\mathrm{za}$, que presentan una buena consistencia interna $(\alpha=$ $0,789)$. Del análisis factorial confirmatorio se concluye que el ajuste del modelo modificado es satisfactorio.

Conclusión: Este instrumento tiene buenos niveles de validez, fidelidad y fiabilidad, los cuales permiten considerar su utilización para evaluar la búsqueda de sensaciones sexuales en jóvenes adultos.

Palabras clave: conducta sexual; estudiantes; educación superior; estudios de validación; sensaciones sexuales

Received for publication: 16.06 .17

Accepted for publication: 21.09.17

Série IV - n. ${ }^{\circ} 15$ - OUT./NOV./DEZ. 2017 


\section{Introduction}

Although taking risks and trying new activities are part of normal youth development, higher education students are more likely to seek new social experiences, namely during academic festivities by having sexual intercourse with occasional partners, unprotected sex, and sexual intercourse under the influence of alcohol and drugs (Burnett et al., 2014; Logan, Koo, Kilmer, Blayney, \& Lewis, 2015). These sexual risk behaviors have also been identified among higher education students in Portuguese academic settings (Cunha-Oliveira et al., 2017; Reis, Ramiro, Matos, \& Diniz, 2013).

Studies have analyzed the search for sexual sensations due to the association between the predisposition to seek complex and intense sexual sensations and risks. The relation between the search for sexual sensation and the exposure to sexually transmitted infections (STIs) has been the main topic of research in the population of university students. Some studies have found higher scores in the search for sexual sensations among students with sexual risk behaviors, namely not using a condom or having sexual intercourse with occasional partners (Gaither \& Sellbom, 2003; Gullette \& Lyons, 2006). Other studies have highlighted the importance of assessing personality traits, not only to understand sexual behaviors, but also to develop interventions for the prevention of HIV/AIDS and other STIs (Hendershot, Stoner, George, \& Norris, 2007; Oshri, Tubman, Morgan-Lopez, Saavedra, \& Csizmadia, 2013). Thus, the identification of young people who are more prone to search for sexual sensations and, consequently, engage in sexual risk behaviors (Oshri et al., 2013), may contribute to the development of nursing interventions aimed at promoting safe sexual behaviors. The purpose of this study is to culturally adapt and validate the Sexual Sensation Seeking Scale (SSSS) for Portuguese higher education students.

\section{Background}

Each individual has specific personality traits that distinguish him/her from other indi- viduals. These traits are essentially internal, relational, or social characteristics that cause individuals to behave in a certain way in particular situations (McMartin, 1995). Most of the research on sexual risk behaviors has been developed based on cognitive and behavioral theories that try to explain the change in health behaviors. However, in recent decades, sexual sensations have gained increasing interest as a predictor for risk behaviors, including an increased risk for STIs (Teva, Bermúdez, \& Buela-Casal, 2010; Voisin, King, Schneider, Diclemente, \& Tan, 2012). The concept of sensation seeking was initially proposed by Zuckerman (1971) as individuals' need for varied, novel, complex, and intense experiences, just for the sake of taking physical and social risks with the purpose of meeting a personal need. Research has shown that individuals with a greater predisposition to engage in sensation seeking behaviors prefer social contexts that involve pleasurable and recreational activities which involve some sort of social, physical, legal, and even financial risks (Pechorro et al., 2015).

Sexual sensation seeking is a specific dimension of sensation seeking which was adapted by Kalichman and Rompa (1995) based on the Sensation Seeking Scale (Zuckerman, 1971). The Sexual Sensation Seeking Scale (SSSS) aims to assess individuals' disposition to seek varied and novel sexual experiences and sensations. The scale has been tested in different countries and populations, namely using samples of higher education students (Gaither \& Sellbom, 2003), young adults (Hendershot et al., 2007; Oshri et al., 2013), and adolescents (DiClemente et al., 2010; Teva et al., 2010). The SSSS was recently validated for Portugal by Pechorro et al. (2015) in a sample of adults. Studies have shown that individuals with higher sexual sensation seeking levels are more sexually permissive, have more sexual partners, use condoms less often (Hendershot et al., 2007; Voisin et al., 2012), have unprotected sexual intercourse under the influence of alcohol or drugs (Gullette \& Lyons, 2006; Oshri et al., 2013, Vu et al., 2017), are unfaithful, watch pornography videos, and seek cybersex (Ballester-Arnal, Castro-Calvo, Gil-Llario, \& Giménez-García, 2013). Studies have also found a strong as- 
sociation between more intense sensation seeking behaviors and the pursuit of a value system based upon hedonism. These individuals feel the need to be constantly stimulated and are highly motivated to use alcohol and drugs (Voisin et al., 2012; Oshri et al., 2013). In view of the above, it is important to use measurement instruments that are validated for the Portuguese population and that may contribute to the planning of specific sexual and reproductive health (SRH) promotion interventions aimed at the population under analysis.

\section{Research question}

What are the psychometric properties of the Portuguese version of the SSSS using a sample of college students?

\section{Methodology}

A cross-sectional and descriptive study was conducted using a sample of 1946 students attending a University in the North region of Portugal, during the 2013/2014 academic year. In a first phase, a total of 37 programs of the five Schools of the University were selected, and classes were grouped based on the scientific area and year of the program. Subsequently, a cluster sampling was performed using the class as cluster or sampling unit. The questionnaire was administered in the classroom, at the end of the teaching session, to all students who accepted to voluntarily participate after being informed about the study objectives and ensured anonymity and confidentiality.

A self-administered questionnaire was used to collect data on the sociodemographic characteristics (gender, age, nationality, place of birth, education, and parents' income), academic aspects (scientific area of study), and sexual and reproductive behaviors (active sexual life, use of contraceptives, contraceptive method used, consistent use of condoms, sexual intercourse under the influence of alcohol and/or drugs or with occasional partners, screening for HIV and STIs), followed by the SSSS that was designed by Kalichman and Rompa (1995). The SSSS is an 11-item unidimensional self-completion scale that assesses seeking sexual sensations as a general construct. Sexual sensation seeking behaviors are assessed on a 4-point scale (ranging from 1- Not at all like me to 4 - Very much like $m e$ ), in which the total score ranges from 11 to 44 points. The questions focus on the adherence to risk behaviors, thus a higher score indicates that the respondent is more prone to seek sexual sensations. The psychometric assessment conducted by the authors of the SSSS showed that the scale has a good internal consistency (Cronbach's alpha coefficient of 0.79 ), and its validation using a sample of North-American higher education students (Gaither \& Sellbom, 2003) also showed adequate psychometric properties (Cronbach's alpha of 0.83 for male students and 0.81 for female students).

Prior to the process of cultural adaptation of the instrument, the authors of the scale were contacted and authorized its use, saying that it can be used freely. The process of translation and adaptation of the instrument followed the steps recommended in the guidelines of several authors (World Health Organization, 2011): preliminary translation from English into Portuguese, review by an expert panel, back-translation, and pre-testing. The different versions (original, translation, and back-translation) were compared and the pre-final version was analyzed by two experts in SRH and one expert in Psychology at the semantic, idiomatic, and conceptual levels. The subsequent consensus version was pre-tested on a sample of 173 students to identify any difficulties in the understanding and interpretation of the items, which resulted in minor syntactic changes. The final version of the SSSS adapted to the Portuguese population was entitled SSSS-P.

Statistical data were analyzed using the IBM SPSS Statistics (v.21) and IBM SPSS AMOS (v.22). Construct validity was assessed through an exploratory factor analysis (EFA) with varimax rotation. Factor structure was selected based on Marôco's guidelines (2014): the Kaiser criterion (eigenvalue $\geq 1.0$ ); item factor loadings $\geq 0.4$; at least $40 \%$ of the total variance explained by the factors; and retention of at least three items per factor. 
Internal consistency reliability was assessed through Cronbach's alpha $(\alpha=0.70)$ and Pearson's correlation coefficient as a measure of item homogeneity. The confirmatory factor analysis (CFA) was used to estimate the model based on the maximum likelihood estimation method and the global fit indices: ratio between the chi-square and degrees of freedom $\left(X^{2} / \mathrm{df}\right)$, Comparative Fit Index (CFI > 0.90), Goodness-of-fit index (GFI > 0.90), Standardized Root Mean Square Residual (SRMSR < 0.08), Root Mean Square Residual (RMSR, where values closer to zero indicate a better fit), and Root Mean Square Error of Approximation (RMSEA < 0.06). Convergent validity was assessed through the average variance extracted (AVE); discriminant validity was analyzed by comparing the AVE with the square of Pearson's correlation coefficient; and construct reliability was calculated through Cronbach's alpha and composite reliability (CR). The reference values were AVE > 0.5 and $C R \geq 0.7$, and discriminant validity was confirmed when the square of the correlation coefficient between factors was lower than the AVE of each individual factor. Since some of the described situations required students to have previous sexual experience, the psychometric characteristics of the scale were analyzed using only those students who had already initiated their sexual activity $(n=1500)$ from among the total number of participants $(n=1946)$. Then, this subsample was randomly divided: the EFA was performed using the first half $(n=747)$, and the CFA was performed using the second half $(n=753)$.

Students were instructed about how to complete the questionnaire using the instructions sheet of the research protocol so as to avoid the exclusion of questionnaires due to errors in completion.

Data were collected after the submission of the research study protocol and its approval by the Board of Directors of the University where the study was conducted. The ethical-deontological principles set forth in the Declaration of Helsinki and the legislation on research involving human beings were safeguarded during the study. The study was approved by the National Commission for Data Protection (Authorization no. 7409/2013) and the Ethics Committee of the University where it was conducted (Opinion no. 2/2012).

\section{Results}

\section{Characteristics of the sample}

The study sample was composed of 1946 students from various scientific areas of a University in the North region Portugal. The participants had a mean age of 21 years $(20.74 \pm$ 2.32 ), $64 \%$ were women and $36 \%$ were men. Most of them were of Portuguese nationality (97.3\%), single (97.6\%), coming from urban areas $(40 \%)$ and low-income families $(57 \%$, $\leq 2$ minimum wages), with low levels of education $(54.5 \%$ of mothers and $61.6 \%$ of fathers only had basic education), and with few specialized professions. The majority of students reported having had sexual intercourse in the last year $(76.9 \%)$ and using contraceptives regularly $(96.7 \%)$. Most men used condoms $(32.1 \%)$ and most women used hormonal contraceptives (52.9\%). Only a small percentage of students had ever been tested for HIV (14.5\%) and STIs (1.3\%). A high percentage of students reported engaging in sexual risk behaviors in the past 12 months, namely sexual intercourse under the influence of alcohol (33.0\%) and drugs (9.7\%), with occasional partners $(32.0 \%)$, and inconsistent condom use $(60.5 \%)$.

\section{Exploratory factor analysis}

The psychometric properties of the SSSS-P were analyzed using the first random subsample $(n=747)$ through the principal components analysis with Varimax rotation (Table 1). The Kaiser-Meyer-Olkin measure (KMO $=0.825)$ and Bartlett's test of sphericity $\left(X^{2}\right.$ $=2056.442, p<0.000)$ were applied to determine the sampling adequacy to the EFA and showed significant inter-variable correlations to proceed with the factor analysis (Marôco, 2014). Since the scale proposed by the authors has a single-factor structure, one component was initially extracted, but the explained variance $(38.43 \%)$ did not fulfill the criteria laid down. Therefore, another analysis was conducted considering eigenvalues and their distribution in the scree plot components, which pointed to a two-factor solution that explained $47.62 \%$ of total variance. 
Table 1

Factors, factor loadings, and communalities of the Portuguese version of the Sexual Sensation Seeking Scale (SSSS-P)

\begin{tabular}{|c|c|c|c|c|}
\hline \multirow{2}{*}{$\begin{array}{l}\text { No. } \\
\text { Items }\end{array}$} & \multirow{2}{*}{ Items } & \multicolumn{2}{|c|}{ Factor Loading } & \multirow{2}{*}{ Communalities } \\
\hline & & Factor 1 & Factor 2 & \\
\hline 11 & $\begin{array}{l}\text { I like to have new and exciting sexual } \\
\text { experiences and sensations }\end{array}$ & 0.838 & & 0.715 \\
\hline 10 & I feel like exploring my sexuality & 0.838 & & 0.702 \\
\hline 9 & $\begin{array}{l}\text { I am interested in trying out new sexual } \\
\text { experiences }\end{array}$ & 0.813 & & 0.689 \\
\hline 1 & I like wild "uninhibited" sexual encounters & 0.483 & & 0.381 \\
\hline 8 & $\begin{array}{l}\text { I have said things that were not exactly true to get a person } \\
\text { to have sex with me }\end{array}$ & & 0.774 & 0.603 \\
\hline 5 & $\begin{array}{l}\text { When it comes to sex, physical attraction is more } \\
\text { important to me than how well I know the person }\end{array}$ & & 0.744 & 0.557 \\
\hline 7 & I enjoy watching "X rated" videos & & 0.628 & 0.471 \\
\hline 4 & My sexual partners probably think I am a "risktaker" & & 0.559 & 0.333 \\
\hline 6 & I enjoy the company of "sensual" people & & 0.558 & 0.482 \\
\hline \multicolumn{2}{|c|}{ Kaiser-Meyer-Olkin measure of sampling adequacy } & \multicolumn{2}{|c|}{0.818} & \\
\hline \multirow{2}{*}{\multicolumn{2}{|c|}{$\begin{array}{l}\text { Bartlett's Test of Sphericity } \\
\text { Eigenvalue }\end{array}$}} & \multicolumn{2}{|c|}{$\mathrm{X}^{2}=1793.780 ; p<0.000$} & \\
\hline & & 3.364 & 1.568 & \\
\hline \multicolumn{2}{|c|}{$\%$ variance explained } & 28.59 & 26.21 & 54.80 \\
\hline
\end{tabular}

In view of the results, the SSSS-P was further analyzed as a two-factor structure during the validation process. Commonalities were generally good, except for items 2 and 3 (0.261 and 0.149 , respectively), which suggested that these items should be deleted. Factor loadings below 0.4 confirmed the elimination of item 2 "The physical sensations are the most important things about having sex" and item 3 "I enjoy the sensation of intercourse without a condom". The factor structure of the scale was then composed of nine items distributed by two factors which explained $54.80 \%$ of total variance $(\mathrm{F} 1=28.59 \%$ and $\mathrm{F} 2=26.21 \%)$.
The first factor consisted of four items (1, 9, $10,11)$ on aspects related to the search for new sexual sensations, and was entitled "Seeking new sexual sensations", while the second factor consisted of five items $(4,5,6,7,8)$ on aspects related to the search for sexually arousing situations, and was entitled "Seeking new sexual experiences". The title of each factor aimed at reflecting the global conceptual content of its items. The subscales showed moderate inter-item correlations (Table 2): 0.275 to 0.613 for subscale F1-"Seeking new sexual sensations", and 0.195 to 0.434 for subscale F2-"Seeking new sexual experiences". 
Table 2

Descriptive results of the items and item-total correlation of the Portuguese version of the Sexual Sensation Seeking Scale (SSSS-P)

\begin{tabular}{|c|c|c|c|c|c|c|}
\hline $\begin{array}{l}\text { Factor } \\
\text { Item }\end{array}$ & Items & Mean & SD & $\begin{array}{l}\text { Corrected } \\
\text { item-total } \\
\text { correlation } \\
\end{array}$ & $\begin{array}{c}\text { Squared } \\
\text { multiple } \\
\text { correlation }\end{array}$ & $\begin{array}{c}\text { Cronbach's } \\
\text { alpha if item } \\
\text { deleted }\end{array}$ \\
\hline \multicolumn{7}{|c|}{ Factor 1 - Seeking new sexual sensations } \\
\hline 1 & I like wild "uninhibited" sexual encounters & 2.23 & 1.086 & 0.388 & 0.167 & 0.818 \\
\hline 9 & $\begin{array}{l}\text { I am interested in trying out new sexual } \\
\text { experiences }\end{array}$ & 2.53 & 0.992 & 0.656 & 0.473 & 0.670 \\
\hline 10 & I feel like exploring my sexuality & 2.56 & 0.980 & 0.612 & 0.452 & 0.695 \\
\hline 11 & $\begin{array}{l}\text { I like to have new and exciting sexual } \\
\text { experiences and sensations. }\end{array}$ & 2.95 & 0.923 & 0.668 & 0.465 & 0.669 \\
\hline \multicolumn{7}{|c|}{ Factor 2 - Seeking new sexual experiences } \\
\hline 4 & My sexual partners probably think I am a "risktaker" & 1.54 & 0.821 & 0.372 & 0.159 & 0.686 \\
\hline 5 & $\begin{array}{l}\text { When it comes to sex, physical attraction is more } \\
\text { important to me than how well I know the person }\end{array}$ & 1.56 & 0.809 & 0.509 & 0.278 & 0.633 \\
\hline 6 & I enjoy the company of "sensual" people" & 2.48 & 1.008 & 0.471 & 0.235 & 0.650 \\
\hline 7 & I enjoy watching "X rated" videos & 1.88 & 0.979 & 0.480 & 0.265 & 0.645 \\
\hline 8 & $\begin{array}{l}\text { I have said things that were not exactly true to get } \\
\text { a person to have sex with me }\end{array}$ & 1.31 & 0.682 & 0.492 & 0.276 & 0.648 \\
\hline \multirow{3}{*}{\multicolumn{2}{|c|}{ Cronbach's alpha coefficient }} & \multicolumn{2}{|c|}{ Factor 1} & \multicolumn{3}{|c|}{0.778} \\
\hline & & \multicolumn{2}{|c|}{ Factor 2} & \multicolumn{3}{|c|}{0.710} \\
\hline & & \multicolumn{2}{|c|}{ Total } & \multicolumn{3}{|c|}{0.789} \\
\hline
\end{tabular}

Corrected item-total correlations ranged between 0.372 (item 4) and 0.668 (item 11). The analysis of the reliability of the 9-item SSSS-P showed moderate internal consistency values for both the subscales and the total scale $(\alpha=0.789)$. The analysis showed a moderate Pearson's correlation between each factor $(r=0.520)$ and a high correlation between both factors and the total scale score (F1-"Seeking new sexual sensations", $r=$ 0.885 ; F2-"Seeking new sexual experiences", $r=0.857)$. These differences were statistically significant $(p<0.01)$.

\section{Confirmatory Factor Analysis}

A CFA was performed to the SSSS-P using the second subsample $(n=747)$ to determine the fitness to data of the factor structure obtained in the EFA. The descriptive analysis of the nine items showed absolute values of skewness and kurtosis below 3 (from 0.009 to 1.994) and 7 (from 0.067 to 2.912), respectively, thus confirming the assumption of normal item distri- bution in the population. In addition, Mardia's multivariate coefficient below 5 (1.025) is consistent with this result. All trajectories and critical ratios were greater than 1.96 and highly significant, thus no item was deleted.

The item loadings below 0.5 in both factors of the initial model (Figure 1a) suggested that item $1(\lambda=0.48)$ of the first factor and item $4(\lambda=0.49)$ of the second factor should be deleted. However, given that this was a preliminary study of the scale and that the values were within the range of the exclusion criterion, both items were maintained in the analysis. In the final model, most global goodness-of-fit indices were appropriate (GFI = $0.941 ; \mathrm{CFI}=0.912 ; \mathrm{RMSR}=0.070 ; \mathrm{SRMSR}$ $=0.075)$, except for indices $\mathrm{X}^{2} / \mathrm{df}=8.600$ and RMSEA $=0.104$. The high goodness-of-fit of the $\mathrm{X}^{2} / \mathrm{df}$ index can be explained by its high sensitivity to sample size (Marôco, 2010). Subsequently, the model was analyzed based on the modification indices proposed in the IBM SPSS AMOS (V22.0) software (Figure 1b). 
$1 a$

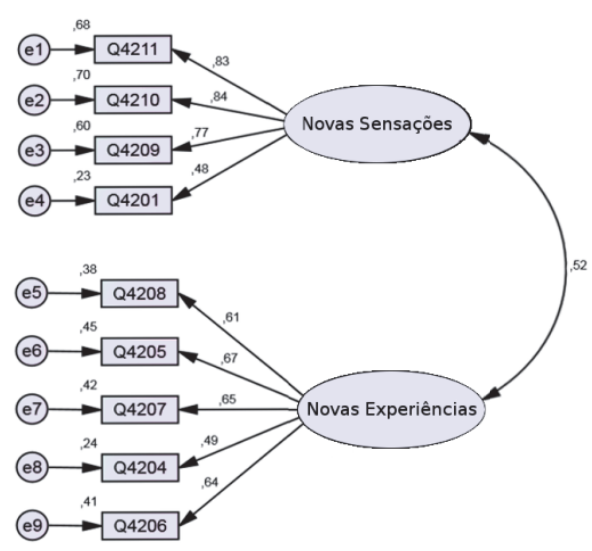

$1 b$

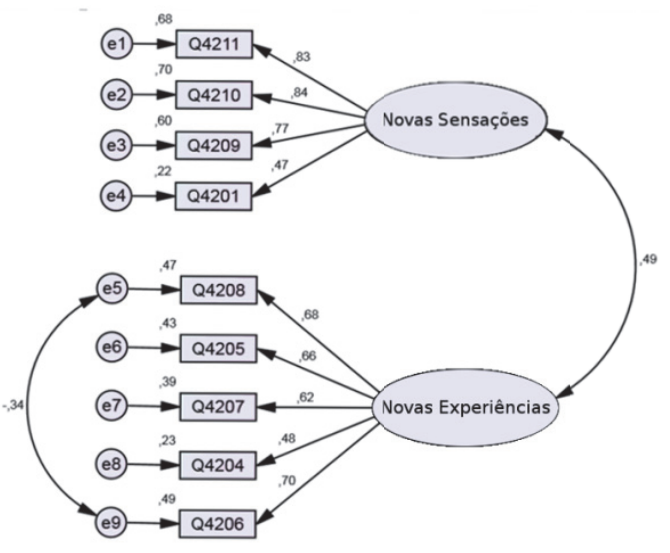

Figure 1. Factor loadings, reliability.

Note. Factor loadings, individual reliability, and correlations between SSSS-P factors. $1 \mathrm{a}=$ initial model; $1 \mathrm{~b}=$ final model.

Although the model revealed collinearity issues between measurement errors 5 and 9, the model's goodness-of-fit indices improved, albeit slightly, showing adequate global goodness-of-fit indices (GFI=0.952; $\mathrm{CFI}=0.927$; $\mathrm{RMSR}=0.071$; $\mathrm{SRMSR}=0.075)$ while the remaining indices were poor $\left(X^{2}\right)$ $\mathrm{df}=7.534$; $\mathrm{RMSEA}=0.093$ ).

Items 1 and 4 continued to show factor loadings below 0.5 , but the remaining items had significant indices, with coefficients greater than 0.62 between factors and their observable manifestations. The correlation between both factors was moderate $(r=0.49)$.

\section{Internal consistency}

Construct reliability was assessed through CR, where values above 0.7 showed a good internal consistency of the items in both factors $\left(\mathrm{CR}_{\mathrm{F} 1}=0.826 ; \mathrm{CR}_{\mathrm{F} 2}=0.768\right)$. Both factors also proved to have an adequate discriminant validity $(0.240)$ since it is lower than the AVE of each factor. Stratified alpha was 0.885 for an AVE of 0.469 , with the latter being slightly below the reference value. Convergent validity (Table 3) was determined by calculating the AVE for each factor and it proved to be adequate for the first factor $\left(\mathrm{AVE} \mathrm{E}_{\mathrm{F}}=0.533\right)$ but not for the second factor $\left(\mathrm{AVE} \mathrm{E}_{\mathrm{F} 2}=0.402\right)$.

\section{Table 3}

Composite reliability, average variance extracted, and Pearson's correlation coefficient of the Portuguese version of the Sexual Sensation Seeking Scale (SSSS-P)

\begin{tabular}{lccc}
\hline Factors & $C R$ & AVE & $\begin{array}{c}\text { square of Pearson's } \\
\text { correlation coefficient }\end{array}$ \\
\hline F1 - Seeking new sexual sensations & 0.826 & 0.533 & 0.240 \\
F2 - Seeking new sexual experiences & 0.768 & 0.402 & \\
\hline
\end{tabular}

Statistically significant gender and age differences were found regarding the search for new sexual sensations to the extent that male students $(\hat{o} 21.88 \pm 5.07$; $q 16.61$ $\pm 4.61 ; p<0.001)$ and older students $(\leq$ 19 years $=17.97 \pm 5.46 ; 20$ to 24 years $=$ $18.68 \pm 5.29 ; \geq 24$ years $=19.36 \pm 5.87 ; p=$
0.005) scored higher in the items related to seeking new sexual sensations.

\section{Discussion}

Several authors have emphasized the impor- 
tance of personality-related variables in risk behaviors, as well as the need to include these variables in theoretical models designed to understand sexual risk behaviors (Hendershot et al., 2007). From this perspective, the use of measurement instruments that are validated and adapted to the Portuguese reality, as in the case of the SSSS, may be relevant to the development of SRH promotion programs.

The psychometric analysis of the SSSS-P through EFA showed a different factor solution from the version proposed by Kalichman and Rompa (1995). In this study, the EFA revealed a two-factor solution, with two items deleted (items 2 and 3), while the the authors of the original version proposed a unidimensional structure. The analysis revealed promising values regarding the total explained variance and factor loadings, which allowed the validation of the two-factor solution. Additionally, the moderate and positive correlations between the total scale and its factors were statistically significant, which supports the conclusion that both factors measure the same construct. Corrected item-total correlations were appropriate, given that they are greater than 0.20 , which is the minimum acceptable value in the literature (Marôco, 2014). Despite this, these values are lower than those reported by Gaither and Sellbom (2003) in a sample of 546 higher education students. During the validation of this instrument in similar populations, particularly in Spanish adolescents (Teva et al., 2010) and North-American higher education students (Gaither \& Sellbom, 2003), the authors maintained the original single-factor structure, despite performing only the EFA. The differences found in the factor structure of the SSSS-P probably reflect the sample size and cultural differences, which must always be taken into account when adapting psychometric instruments for different countries.

In this study, both EFA and CFA pointed to the deletion of item 2 "The physical sensations are the most important things about having sex" and item 3 "I enjoy the sensation of intercourse without a condom". The exclusion of these items can be associated with gender differences. Most of the sampled participants were women, who assign greater importance not only to the component of affection in re- lationships but also to preventive measures, such as the use of condoms for protection against unwanted pregnancies and STIs (Reis et al., 2013). In addition, there are still some myths associated with the loss of sexual pleasure and a decrease in the erotic-hedonist dimension of sexuality when using a condom, particularly among men. In a recent study conducted with higher education students, Cunha-Oliveira et al. (2017) have pointed to the importance of the implementation of safe sex promotion campaigns among young University students through condom social marketing programs so as to increase condom use, even with regular sexual partners. The results of this study confirm that the study of sexual sensation seeking behaviors should consider gender and age variables, because men, particularly young men ( $\geq 24$ years), scored higher in the search for sexual sensations, which is in line with those obtained in other studies (Teva et al., 2010; Gullette \& Lyons, 2006).

CFA results showed that both factors have an adequate internal consistency, which despite only confirming convergent validity for the first factor. The final factor solution confirmed a two-factor structure, in which the first factor F1- "Seeking new sexual sensations" is the most important factor for measuring the construct in this study. Overall, construct validity was satisfactory and construct reliability was good, which allows considering the use of the Portuguese version of the SSSS-P in research studies with higher education students.

One of the limitations of this study was the use of a non-random sampling technique, which prevents the generalization of results. This limitation may have been minimized by the randomization of the student classes to collect data and of the subsamples to perform the CFA. Furthermore, self-reported behavioral intentions may not be accurate measures of actual behaviors. Another limitation was the use of a four-point scale, to the extent that the lack of a neutral answer may have reduced the information capacity of analysis and limited the quality of estimation. In view of the above, we recommend that the psychometric properties of the SSSS-P should be further evaluated by assessing the temporal stability and adequacy of the two-factor structure in 
an independent sample. This sample should not be the same sample that was used to test the goodness-of-fit of the model, and should be more representative of the population under analysis.

\section{Conclusion}

The initial evaluation of the psychometric characteristics showed that SSSS-P has promising validity and reliability. The final two-factor structure obtained in the CFA, although different from the solution proposed by the authors of the original scale, is suitable for use since it shows a reasonable fit to data. The process of cultural adaptation and validation for Portuguese higher education students has demonstrated that the SSSS-P is an accurate and easy-to-apply instrument. It can be useful in the planning of health interventions, where it is important to assess individuals' willingness to take sexual risks.

\section{References}

Ballester-Arnal, R., Castro-Calvo, J., Gil-Llario, MD., Giménez-García, C. (2013). Relationship status as an influence on cybersex activity: Cybersex, youth, and steady partner. Journal of Sex \& Marital Therapy, 40(5), 444-456. doi:10.1080/009262 3X.2013.772549

Burnett, A. J., Sabato, T. M., Walter, K. O., Kerr, D. L., Wagner, L., \& Smith, A. (2014). The influence of attributional style on substance use and risky sexual behavior among college students. College Student Journal, 48(2), 325-336.

Cunha-Oliveira, A., Caramelo, F., Patrício M., Camareiro, A. P., Massano-Cardoso, S. \& Pita, J. R. (2017). Impacto de um programa de intervenção educativa nos comportamentos sexuais dos estudantes universitários. Revista de Enfermagem Referência, 13(4), 71-82. doi:10.12707/RIV17022

DiClemente, R., Milhausen, R. R., Salazar, L. F., Spitalnick, J., Sales, J. M., \& Crosby, R. A., ... Wingood, G. M. (2010). Development of the Sexual Sensation-Seeking Scale for African American Adolescent Women. International Journal of Sexual Health, 22(4), 248-261. doi:10.1080/19317611.2010.491388

Gaither, G. A., \& Sellbom, M. (2003). The sexual sensation seeking scale: Reliability and validity within a heterosexual college student sample. Journal of Personality Assessment, 81(2), 157-167. doi:10.1207/ S15327752JPA8102_07

Gullette, D. L., \& Lyons, M. A. (2006). Sensation seeking, self-esteem, and unprotected sex in college students. Journal of Association of Nursing in AIDS Care, 17(5), 23-31. doi:10.1016/j.jana.2006.07.001

Hendershot, C. S., Stoner, S. A., George, W. H., \& Norris, J. (2007). Alcohol use, expectancies, and sexual sensation seeking as correlates of HIV risk behavior in heterosexual young adults. Psychology of Addictive Behaviors, 21(3), 365-372. doi:10.1037/0893164X.21.3.365

Kalichman, S. C., \& Rompa, D. (1995). Sexual Sensation Seeking and Sexual Compulsivity Scales: Reliability, validity, and predicting HIV risk behavior. Journal of Personality Assessment, 65(3), 586-601. doi:10.1207/s15327752jpa6503_16

Logan, D. E., Koo, K. H., Kilmer, J. R., Blayney, J. A., \& Lewis, M. A. (2015). Use of drinking protective behavioral strategies and sexual perceptions and behaviors in U.S. college students. Journal of Sexual Research, 52(5), 558-569. doi:10.1080/00224499. 2014.964167

Marôco, J. (2010). Análise de equaçōes estruturais: Fundamentos teóricos, software \& aplicaçōes. Pêro Pinheiro, Portugal: Report Number.

Marôco, J. (2014). Análise estatística com o SPSS statistics. Pêro Pinheiro, Portugal: Report Number.

McMartin, J. (1995). Personality psychology: A student-centered approach. London, England: Sage Publications.

Oshri, A., Tubman, J. G., Morgan-Lopez, A. A., Saavedra, L. M., \& Csizmadia, A. (2013). Sexual sensation seeking, co-occurring sex and alcohol use, and sexual risk behavior among adolescents in treatment for substance use problems. American Journal on Addictions, 22(3), 197-205. doi:10.1111/j. 1521-0391.2012.12027.x

Pechorro, P., Pascoal, P., Figueiredo, C., Almeida, A. I., Vieira, R., \& Jesus, S. (2015). Validação portuguesa da Escala de Busca de Sensaçóes Sexuais. Revista Internacional de Andrología, 13(4), 125-130. doi:10.1016/j.androl.2014.11.003

Reis, M., Ramiro, L., Matos, M. G., \& Diniz, J. A. (2013). Determinants influencing male condom use among university students in Portugal. International Journal of Sexual Health, 25(2), 115-127. doi $: 10.1080 / 19317611.2012 .728554$

Teva, I., Bermúdez, M. P., \& Buela-Casal, B. (2010). Sexual sensation seeking, social stress, and coping styles as predictors of HIV/STD risk behaviors 
in adolescents. Youth \& Society, 42(2), 255-277. doi:10.1177/0044118X09353572

Voisin, D., King, K., Schneider, J., Diclemente, R., \& Tan, K. (2012). Sexual sensation seeking, drug use and risky sex among detained youth. Journal of AIDS \& Clinical Research, Sup.1, 1-5. doi:10.4172/21556113.S1-017

Vu, N. T., Holt, M., Phan, H. T., La, L. T., Tran, G. M., Doan, T. T., ... Wit, J. (2017). The relationship between methamphetamine use, sexual sensation seeking and condomless anal intercourse among men who have sex with men in Vietnam: Results of a community-based, cross-sectional study. AIDS Behaviour, 21(4), 1105-1116. doi:10.1007/ s10461-016-1467-x

World Health Organization. (2011). Process of translation and adaptation of instruments. Retrieved from http://www.who.int/substance_abuse/research_ tools/translation/en/

Zuckerman, M. (1971). Dimensions of sensation seeking. Journal of Consulting and Clinical Psychology, 36(1), 45-52. doi:10.1037/h0030478 